\title{
Asymmetric Granger Causality between Military Expenditures and Economic Growth in Top Six Defense Spenders
}

\author{
Abdulnasser Hatemi-J \\ Department of Economics and Finance \\ UAE University, P.O. Box 15551, Al Ain, UAE \\ Email: AHatemi@uaeu.ac.ae \\ Tsangyao Chang \\ Department of Finance \\ Feng Chia University, Taichung, TAIWAN \\ Email: tychang@mail.fcu.edu.tw \\ Wen-Yi Chen \\ Department of Senior Citizen Service Management, \\ College of Health, National Taichung University of Science and Technology, \\ Taichung, TAIWAN. \\ Email: chenwen@ nutc.edu.tw \\ Feng-Li Lin \\ Department of Accounting \\ Chaoyang University of Technology, Taichung, TAIWAN \\ Email: bonnie@cyut.edu.tw \\ Rangan Gupta \\ Department of Economics, University of Pretoria, Pretoria, 0002, SOUTH AFRICA \\ Email: rangan.gupta@up.ac.za
}

\begin{abstract}
This study applies asymmetric Granger causality test, proposed by Hatemi-J (2011; 2012) to revisit military expenditures-growth nexus for the world top 6 defense spenders over 1988-2013. Empirical results indicate that the military expenditure-led hypothesis is supported in China and Japan. However, the growth-led hypothesis is supported in four countries, i.e. France, Russia, Saudi Arabia and US. Except for Saudi Arabia, strong economic growth by no means implies automatic expansion of military expenditures. Defense planning in these countries is a matter of matching their limited resources to attain the suitable priorities. The more threats they perceived, the more military spends. This evidence provides useful insight into the behavior of other potential defense suppliers.
\end{abstract}

JEL Codes: C33, H56, O40

Keywords: Growth, Military Expenditures, Symmetric and Asymmetric Panel Granger Causality 


\section{Introduction}

Since Benoit's influential works showed strong positive correlation between high defense burdens and rapid economic growth rate in developing countries (Benoit, 1973; Benoit, 1978), many studies have been done on the relationship between military expenditure and economic growth. For example, Dunne and Tian (2013) extended and updated from an earlier survey by Dunne and Uye (2010) reviewed 168 studies investigating the defense-growth relationship, among which most of studies generated insignificant (approximately 40\%) or a negative correlation (approximately $38 \%$ ) between military expenditure and economic growth. Only approximately onefifth of these studies generated a positive effect of military expenditure on economic growth. The ambiguous results in the sign of the correlation between military expenditure and economic growth were also confirmed in the recent meta-analysis research on the defense-growth relationship conducted by Alptekin and Levine (2012). In particularly, they concluded that a negative military expenditure- growth relationship is not supported for both less developing countries and developed countries, but a positive military expenditure-growth relationship is supported for developed countries. Based on these comprehensive literature surveys, the nature of the linkages between military expenditure and economic growth is ambiguous, and a deeper investigation into the mechanism is called for.

In a consecutive series of recent studies by Chang et al.,(2014), Pan et al.,(2014); and Zhong et al., (2014), Chang and his colleagues suggested that the mechanisms underlying the direction of causality linking military expenditure and economic growth can be classified into four possible hypothetical structures: the military expenditure-led, the growth-led, feedback, and neutrality hypotheses. The possible mechanism of the military expenditure-led hypothesis suggests a causal linkage between military expenditure and economic growth running from military expenditure 
to economic growth. Previous studies provided possible explanations for this causal linkage. Dune et al (2005) proposed that a possible unidirectional causality running from military expenditure to economic growth is channeled through the demand, supply, and security effects. The demand effects based on the Keynesian theory generate two contradictory effects in the sign of correlation between military expenditure and economic growth. The positive effect of military expenditure on the economic growth is based on the Keynesian multiplier effect, meaning that an increase in military expenditure will reduce both spare capacity of resources and unemployment, and in turn increase the economic growth. The negative effect of military expenditure on the economic growth, however, is rooted on the opportunity cost of military expenditure or the crowding-out effect of military expenditure on other forms expenditure such as investments in physical and human capitals. The supply effects operate through the aggregate production function where the availability of factors of production such as labor, physical and human capitals, natural resources, and technology determines the potential outputs and creates externalities (such as commercial spin-off and less productive workers). The security effects are underpinned by the Marxist thought suggesting that military expenditure is necessary to capitalist development so that a rise in military expenditure may increase aggregate output through the security of capital and people from domestic or foreign threats.

As for the perspective of the growth-led hypothesis, it implies a possible unidirectional causality running from economic growth to military expenditure. This hypothesis is directly related to the demand theory for military expenditure (Nikolaodou, 2008; Dunne et al., 2003). Military expenditure is positively associated with economic growth due to the public good nature of defense. The feedback hypothesis on the relationship between military expenditure and economic growth is 
well-documented by Dunne and Smith (2010), and this bi-directional causality between military expenditure and economic growth can be described as the following process: an increase in military expenditure tends in various ways (such as the demand and supply, and security effects) to impact economic growth. Meanwhile, economic growth encourages further demand for defense to assure the capitalist development. The neutrality hypothesis on the relationship between military expenditure and economic growth argues that military expenditure does not rise with economic growth but with the increase of conflicts and threats. Since these four different hypotheses have their own merit in developing an appropriate military strategy, the purpose of this study is to investigate the defense-growth nexus, taking the possible asymmetric relationship causal linkages between military expenditure and economic growth in the top six defense suppliers, namely, the United States (US), Russia, Japan,Saudi Aragia, France, and China.

In fact, there is a great deal of literature investigating the causal relationship between military expenditure and economic growth. For example, Topcu and Aras(2015) applied the conventional vector error model (VECM) and TodaYamamoto(1995)'s procedure to analyze the defense-growth nexus for the European Union from the period of 1973-2010. They found that none of these four hypotheses regarding causality of military expenditure and economic growth prevail in the European Union. The conventional VECM was also adopted in three recent studies on causal linkage of military expenditure and economic growth (or development) in China (Dimitraki and Ali, 2015; Furuoka et al., 2014) and India (Tiwari and Tiwari, 2010). The growth-led hypothesis implying a unidirectional Granger causality running from economic growth (or development) to military expenditure, was found in China, while the feedback hypothesis encompassing a bidirectional Granger causal relationship between military expenditure and economic was confirmed in India. In 
addition to the conventional VECM following the Granger causality tests to verify the defense-growth nexus, many recent studies applied the autoregressive distributed lag (ARDL) bound tests approach to evaluate long-run and lead-lag relationship between military expenditure and economic growth in India (Khalid and Mustapha, 2014; Tiwari and Shahbaz, 2013), Pakistan (Shahbaz and Shabbir, 2013), four Asian countries (Safdari et al., 2011), and top 15 countries with the highest military expenditure (Topcu and Aras, 2013). The military expenditure-led hypothesis was supported in Canada, German, Italy, Pakistan, Russia, UK, and the USA, while the growth-led was supported in Australia, Brazil, China, India, Saudi Arabia, South Korea, Malaysia, and Turkey. The feedback hypothesis was justified in India, and the neutrality hypothesis was found in Iran, Saudi Arabia, and Japan.

Contrast to the time-series model using the individual country data, there is another strand of studies pooling the time series and cross-sectional data into analyses of the defense-growth nexus. Some recent studies utilized the homogeneity panel data models to obtain the unified causal relationship in a group of countries (Chen et al., 2014; Chang et al., 2013; Topcu et al., 2013; Chang et al., 2011; Pradhan, 2010; Kollia et al., 2007). Others recent research employed the heterogeneity panel data models to obtain the individual causal relationship in a group of countries (Chang et al., 2014; Pan et al., 2014). For the examples of the homogeneity panel data models, Chen et al., (2014), Chang et al., (2011), and Kollia et al.(2007) utilized the dynamic generalized moment method (GMM) together with panel causality tests to identify the unified causal relationship in a group of 137,90 , and 15 countries, respectively, while Chang et al.(2013), Topcu et al.(2013), and Pradhan (2010) employed the panel VECM together with panel causality tests to explore the unified lead-lag relationship between military expenditure and economic growth in a group of 15,28 , and 4 countries, respectively. In general, the homogeneity panel data models showed 
various results (in terms of our four different hypotheses) depending on the different regions, time periods, and econometric models used in the analyses. For the instances of the heterogeneity panel data models, Chang et al., (2014), and Pan et al., (2014) applied the bootstrap panel causality test approach to investigated the defense-growth nexus in China and G7 countries, and Middle East countries, respectively. The methodology used in their studies incorporating both cross-countries dependency and heterogeneity with the estimation process of the Granger causality tests. The lead-lag relationship in for each individual country within the panel data can be generated. The results obtained from the heterogeneity panel data model also suggested mixed results (in terms of our four different hypotheses) depending on the different regions and time periods used in the analyses.

It is important to address that previous research on the casual relationship between military expenditure and economic growth ignored the possible asymmetric effect of military expenditure on economic growth, vice versa. In the defense and peace economics literature, the threshold autoregressive (TAR) models are frequently used to model the asymmetric correlation between military expenditure and economic growth (Ali and Dimitraki, 2014; Cuaresma and Reitschuler, 2011; Yang et al., 2011; Lai et al., 2005). Nevertheless, the research incorporating asymmetric causality between military expenditure and economic growth is limited in the literature. To the authors' best knowledge, Kollias and Paleologou (2011) is probably the only published research dealing with the possibility of nonlinear causality between military expenditure and economic growth. The nonlinear Granger causality test developed by Baek and Brock (1992) was used in their study to remove the linear predictive power in the VAR model so that any nonlinear causal relationship between military expenditure and economic growth can be identified. Although Baek and Brock (1992)'s nonlinear Granger causality test is capable of identifying the existence of 
nonlinear causality, it is not able to provide the further information about the asymmetric effect of military expenditure on economic growth, vice versa.

In order to establish an empirical model with a strong theoretical foundation that can truly identify asymmetric causality between military expenditure and economic growth, we applied the newly developed asymmetric causality test proposed by Hatemi-J (2011) to identify the Granger causal relationship between military expenditure and economic growth in the top six defense spenders, namely, the United States (US), Russia, Japan, Saudi Arabia, France, and China over the period of 19882013. Therefore, this study makes several contributions beyond those of the existing research on the military expenditure-growth nexus in three respects. First, this study accentuate on the military expenditure-growth nexus in the top six defense spenders (i.e., the US, Russia, Japan, Saudi Arabia, France, and China - based on SIPRI 2013 report). The mechanisms underlying the direction of causality linking military expenditure and economic growth in these six countries are important because this group of countries represent the largest economy entity, and their military expenditures contributed to approximately $61 \%$ of world military expenditures in 2014 (SIPRI, 2015). In addition, due to the similar trend of military expenditures, this group of countries also can prevent a possible bias from country heterogeneity in determining the causality relation between military expenditure and economic growth. Second, despite asymmetric Granger causality has been studied extensively in the fields of applied economics (Gozhor, 2014; Tiwari, 2014; Hatemi-J, 2012; Mocan and Bali, 2010), this study investigated the asymmetric Granger causal linkage between military expenditure and economic growth in the top six defense spenders (i.e., the US, Russia, Japan, Saudi Arabia, France, and China) over the period of 1988-2013 for the first time, contributing to the literature on the military expenditure-growth nexus. Third, unlike the previous studies investigating the nonlinear causality linking 
military expenditure and economic growth in which the asymmetric causal responses of military expenditure (or economic growth) to an economic shock (a shock of military expenditure) are not available, this study transformed military expenditure and economic growth into cumulative positive and negative changes of military expenditure and economic growth rates that allow us to understand the mechanisms underlying the direction of causality linking a positive (negative) shock in military expenditure and a positive(negative) economic shock is asymmetric. Our model specification incorporating asymmetric innovation in both military expenditure and economic growth will provide a more complete picture of the causal relationship between military expenditure and economic growth than previous studies.

This study is organized as follows: Section 2 describes the empirical model and data. Section 3 shows the results of the asymmetric Granger causality tests in the top six defense suppliers (i.e., the US, Russia, Japan, Saudi Arabia, France, and China) over the period of 1988-2013. Section 4 presents the some remarks and conclusions of this study.

\section{Empirical Model and Data Sources}

\subsection{Data Sources}

The annual data used in this study covers the period from 1988 to 2013 for both the world top 6 defense spenders (i.e., the US, Russia, Japan, Saudi Arabia, France, and China). The variables used in this study include the per capita real military expenditure $(P R M E)$ and the per capita real GDP $(P R G D P),{ }^{1}$ all of which are measured in constant 2005 US dollars. PRGDP have been taken from the World Development Indicators (WDI, 2014), whereas the PRME from the Stockholm

\footnotetext{
${ }^{1}$ We use per capita numbers for two following reasons. First, per capita numbers are less sensitive to territorial changes. Second, per capita numbers provide variables in the same units for large and small countries and they control for the scale of the economy.
} 
International Peace Research Institute (SIPRI, 2014).

\subsection{Empirical Model -Asymmetric Granger Causality Test by Hatemi-J (2011):}

The Hatemi-J (2011) test allows for asymmetric causal effects within the panel system. Thus, positive or negative shocks may have different causal impacts according to this approach. Presume that the focus is on testing for causal nexus of two integrated variables $w_{1}$ and $w_{2}$ in a panel model. The recursive solution for each mentioned integrated variable can be presented as the following:

$$
\begin{aligned}
& w_{i 1, t}=w_{i 1, t-1}+e_{i 1, t}=w_{i 1,0}+\sum_{j=1}^{t} e_{i 1, j} \\
& w_{i 2, t}=w_{i 2, t-1}+e_{i 2, t}=w_{i 2,0}+\sum_{j=1}^{t} e_{i 2, j}
\end{aligned}
$$

For $i=1, \ldots, N$. Where $N$ represents the cross sectional size and $e$ is an error term, which is assumed to be a white noise process. The underlying shocks defined as $e_{i 1, t}^{+}:=\max \left(e_{i 1, t}, 0\right), e_{i 2, t}^{+}:=\max \left(e_{i 2, t}, 0\right), e_{i 1, t}^{-}:=\min \left(e_{i 1, t}, 0\right)$ and $e_{i 2, t}^{-}:=$ $\min \left(e_{i 2, t}, 0\right)$. These values can be used in order to obtain the cumulative sums of the shocks, (i.e. $w_{i 1, t}^{+}, w_{i 2, t}^{+}, w_{i 1, t}^{-}$and $\left.w_{i 2, t}^{-}\right)$as follows

$$
\begin{aligned}
& w_{i 1, t}^{+}=w_{i 1,0}^{+}+e_{i 1, t}^{+}=w_{i 1,0}+\sum_{j=1}^{t} e_{i 1, j}^{+} \\
& w_{i 2, t}^{+}=w_{i 2,0}^{+}+e_{i 2, t}^{+}=w_{i 2,0}+\sum_{j=1}^{t} e_{i 2, j}^{+} \\
& w_{i 1, t}^{-}=w_{i 1,0}^{-}+e_{i 1, t}^{-}=w_{i 1,0}+\sum_{j=1}^{t} e_{i 1, j}^{-} \\
& w_{i 2, t}^{-}=w_{i 2,0}^{-}+e_{i 2, t}^{-}=w_{i 2,0}+\sum_{j=1}^{t} e_{i 2, j}^{-}
\end{aligned}
$$

The asymmetric panel causality test by using a vector autoregressive seemingly 
unrelated regression model of order $p, \operatorname{VAR}-\operatorname{SUR}(p)$. This model is efficient because it accounts for the potential dependency of the error terms across the cross sectional units. Presume that the focus is on testing for causality between positive changes. Then, the vector $\left(w_{i 1, t}^{+}, w_{i 2, t}^{+}\right)$can be used to estimate the following $\operatorname{VAR}-\operatorname{SUR}(p)$ model:

$$
\left[\begin{array}{l}
w_{i 1, t}^{+} \\
w_{i 2, t}^{+}
\end{array}\right]=\left[\begin{array}{l}
\beta_{i 0} \\
\gamma_{i 0}
\end{array}\right]+\left[\begin{array}{ll}
\sum_{r=1}^{p} \beta_{i 1, r} & \sum_{r=1}^{p} \beta_{i 2, r} \\
\sum_{r=1}^{p} \gamma_{i 1, r} & \sum_{r=1}^{p} \gamma_{i 2, r}
\end{array}\right] \times\left[\begin{array}{l}
w_{i 1, t-r}^{+} \\
w_{i 2, t-r}^{+}
\end{array}\right]+\left[\begin{array}{c}
\varepsilon_{i 1, t}^{+} \\
\varepsilon_{i 2, t}^{+}
\end{array}\right]
$$

Where $\varepsilon_{i 1, t}^{+}$and $\varepsilon_{i 2, t}^{+}$are the residuals. The null hypothesis that $w_{i 2, t}^{+}$does not cause $w_{i 1, t}^{+}$is defined as

$$
H_{0}: \beta_{i 2, r}=0, \forall r \text {. Where } r=1, \ldots, p .
$$

Similarly, if the focus is on testing for causality between negative components then the vector $\left(w_{i 1, t}^{-}, w_{i 2, t}^{-}\right)$can be used. It should be mentioned that the cumulative sums of the underlying shocks are produced via an algorithm that is written in Gauss. This software component is available on request.

\section{Empirical Results and Policy Implications}

Table 1 present the descriptive statistics of the annual data for the world top 6 defense spenders (i.e., China, Japan, France, Russia, Saudi Arabia and the US). As showed in Table 2, the GDP ranges from 2302.219 (China) to 43486.55 (in the US) across these six countries over the period from 1988 to 2013. The largest economic growth variability is found in US, followed by Japan, France, Russia, Saudi Arabia, and China. The military expenditures range from 16642.22 (Saudi Arabia) to 522115(in the US) across these six countries over the period from 1988 to 2013. The largest military expenditure variability is also found in US, followed by Russia, France, China, Japan, and Saudi Arabia. We work with the data transformed into its natural 
logarithmic values. Figures A1 and A2 plot the data in the Appendix.

Table 2 demonstrates the cross-sectional dependence and slop homogeneity tests.

As indicated in Table 2, the values of the three different test statistics $\left(C D_{B P}, C D_{L M}\right.$, and CD) are 164.525, 26.204, and 5.402, respectively, which provides strong evidence to reject the null hypothesis of cross-sectional dependence between military expenditure and economic growth across the countries at the $1 \%$ significance level. Table 2 also presents the results of the slope homogeneity tests (Swamy, 1970; Pesaran and Yamagata, 2008). The three different test statistics $\left(\tilde{\Delta}, \tilde{\Delta}_{a d j}\right.$, and Swamy) are15.479, 16.418, and 25.456, respectively, and show that the null hypothesis of slope homogeneity is also rejected at the $1 \%$ significance level. The rejection of slope homogeneity implies that the panel causality analysis by imposing the homogeneity restriction on the variable of interest will result in misleading statistical inferences and thus misleading conclusions on both the strength and direction of causality. In this scheme of things, the direction of causal linkages between military expenditure and economic growth for the world top 6 defense spenders' countries is rather heterogonous or, in other words, the directional causal linkages between the variables of interest may differ across these countries. As a whole, the existence of crosssectional dependency and heterogeneity across countries suggests the suitability of our empirical framework based on the bootstrap panel causality test.

Note that, while our approach of Granger causality does not require determining the order of integration of the two series, we need to ensure that the two series are in fact random walk to decompose per capita real military expenditure (PRME) and the per capita real GDP $(P R G D P)$ into its positive and negative components. As indicated in Table 3, the Im, Pesaran and Shin (, IPS) test under the assumptions constant; and constant and trend in the equation for unit root test, indicates that the two variables are 
in fact indeed $I(1)$. In other words, the series can be decomposed into its positive and negative components as outlined in Subsection 2.3.

Table 4 displays the results that causality running from military expenditure to economic growth, or vice versa for 6 countries in the sample. The symmetric causality test results demonstrate the null hypothesis (i.e. military expenditure does not Granger cause economic growth) can only be rejected for both China and Russia. The estimated causal parameter is 0.19703 and -0.078996 , respectively. This means that a $1 \%$ permanent shock in military expenditure can increase economic growth by $0.19703 \%$ for China, but decrease economic growth by $0.078996 \%$ for Russia. On the other hand, regarding asymmetric Granger causality test, we find the asymmetric causality null hypothesis of a positive shock in military expenditure not causing a positive shock in economic growth is rejected only for China at a $1 \%$ level of significance. The estimated causal parameter is 0.249709 , which means that an increase $1 \%$ in military expenditure can promote economic growth by $0.249709 \%$ for China. Conversely, the null hypothesis that a negative shock in military expenditure does not cause a negative shock in economic growth is rejected only for Japan at a $1 \%$ level of significance. The estimated causal parameter is 1.800843 , which means that reduction a $1 \%$ in military expenditure can decrease economic growth by $1.800843 \%$ for Japan. In other words, decreasing military expenditure can be harmful to economic growth for Japan. For the rest of France, Saudi Arabia and the US, we find that none of the hypothesis that military expenditure does not cause economic growth can be rejected.

Regarding the null hypothesis of the symmetric test that economic growth does not cause military expenditures, we find that this hypothesis can be rejected in three countries (i.e., Russia, Saudi Arabia and the US). The estimated causal parameter is 1.401690, 1.372407and -1.445270 for Russia, Saudi Arabia, and the US, respectively. 
This means that a $1 \%$ permanent shock in economic growth can increase military expenditure by $1.401690 \%$ for Russia and $1.372407 \%$ for Saudi Arabia respectively, but decrease by $1.445270 \%$ for the US. Regarding the asymmetric Granger causality test, the null hypothesis that a positive shock in economic growth does not have a positive impact on military expenditure is rejected in the four countries, i.e. France, Russia, Saudi Arabia and the US. The estimated parameters are negative (-0.941577 and -1.025666) for both France and the US, however, positive (1.947112 and 2.979637) for both Russia and Saudi Arabia. This means that increasing economic growth can deduct the military expenditure for both France and the US and on the other hand, increasing economic growth can enhance the military expenditure for both Russia and Saudi Arabia.

The null hypothesis that a negative shock in economic growth does not cause shocks in the military expenditure can be rejected for both France and Saudi Arabia respectively. We find both the estimated parameters are positive $(0.927676$ and 4.730338) respectively. This means that economic growth can shrink the military expenditure for both France and Saudi Arabia. Regarding China and Japan, we do not find any asymmetric causal link running from economic growth to military expenditure.

In sum, the previous research suggests four possible hypotheses regarding causal relationships between military expenditure and economic growth: the military expenditure-led-growth, the growth-led-military expenditure, feedback, and neutrality hypotheses. The military expenditure-led hypothesis and the growth-led hypothesis present two different positions concerning the relationship between military expenditure and economic growth. While the military expenditure-led hypothesis based on the Keynesian approach causality runs from military expenditure to economic growth, the growth-led hypothesis postulates that causality runs in the 
opposite direction. The feedback hypothesis claims bi-directional causality between the two variables; and finally, a lack of any causal relationship is neutrality hypothesis. There are several interesting findings need to be noted in our study. First of all, our results show that the military expenditure-led hypothesis is supported in China and Japan. This means that an increase in military expenditure can promote economic growth through an expansion of aggregate demand (the Keynesian effect) in China, supporting earlier study (Benoit, 1978) that the resulting increased demand cause the increased use of or else idle capital, higher employment and profits, and therefore higher investment, all of which lead economic growth. In contrast to Japan, reducing military expenditure cause economic growth decrease and not vice versa. Therefore, it is not enough activate productive military expenditures to achieve economic growth. In our opinion, with the vulnerability of revenues to external shocks, Japan sustain an optimal level of military expenditure to avoid economic growth decrease is still a major challenge. Secondly, the growth-led hypothesis is supported in four countries, (i.e. France, Russia, Saudi Arabia and US). In the case of France, either upturn or downturn in economic growth can cause military expenditure to reduce. Especially, from the point of view of European Union and France, Mediterranean region has a strategic importance. If they feel less threat, they decrease defense spending no matter the economy is healthy or not. More interestingly, Increasing economic growth in Russia stimulates military expenditure and vice versa decreasing its economy further reduces it military expenditures. This means that expanding military expenditure is seen as the product of economic development in Russia. In the case of Saudi Arabia, economic development results in the expansion of military expenditures, whereas increasing economic growth cause military expenditure decrease in US. Saudi Arabia, as pointed by Joerding (1986) that a growing country may want to strengthen itself against foreign or domestic threats by increasing its military spending. The possible 
reason is that Russia and Saudi Arabia are able to increase military spending due to increasing in both oil and gas revenues, resulting in economic growth. Regarding the US, even though its economy is the largest in the world, the high military spending may be unable to bear in the long term.

\section{Conclusions}

This study revisits the military expenditures-growth nexus for the world top 6 defense spenders: China, Japan, Russia, Saudi Arabia, France, and the US, using the asymmetric Granger causality test, proposed by Hatemi-J (2011; 2012) over 19882013. Our empirical results show that results from each country is unique and strong economic growth by no means implies automatic expansion of military expenditures. In fact, the observed threats from abroad may be the most important factor contributing to increases in military expenditures. The military expenditure-led hypothesis is supported in both China and Japan. China, the world's emerging economic powers, is exhibiting a sustained increase in their military expenditure which contributes to the world-military-spending growth. China's increasing military expenditure is largely equal to its economic growth. Moreover, reducing its military expenditure resulting in economic growth decrease, Japan maintains an optimal level of military expenditure to evade economic growth downturn. However, the growthled hypothesis is supported in four countries, i.e. France, Russia, Saudi Arabia and the US. But both upturn and downturn in economic growth can reduce military expenditure in France and only upturn in economic growth can cause military expenditure to decrease in US. Defense planning in these two countries is a matter of matching their limited resources to attain the suitable priorities. Increasing economic growth in Russia stimulates military expenditure and vice versa decreasing its economy reduces its military expenditures. Apparently, GDP is an important factor 
for determining how much the Russia could afford to spend on it military expenditures. For Saudi Arabia, a growing economy may be resulting in the expansion of military expenditures, may want to strengthen itself against foreign or domestic threats by increasing its military expenditures. Our empirical evidence should have important policy implications for these world top 6 defense spenders.

\section{References}

Ali, F.M., Dimitraki, O. (2014) Military spending and economic growth in China: a regime-switching analysis. Applied Economics, 46(28), 3408-3420.

Alptekin, A., Levine, P. (2012) Military expenditure and economic growth: a metaanalysis. European Journal of Political Economy. 28, 636-650.

Benoit, E. (1973) Defense and growth in developing countries. Boston MA: Health, Lexington Books.

Benoit, E. (1978) Growth and defense in developing countries. Economic Development and Cultural Change. 26(2), 271-280.

Chang, H.C., Hung, B.N., Yang, C.W. (2011) Military expenditure and economic growth across different groups: a dynamic panel Granger-causality approach. Economic Modelling, 28, 2416-2423.

Chang, T., Lee, C.C., Chu, H.P. (2015) Revisiting the defense-growth nexus in European Countries. Defence and Peace Economics, 26(3), 341-356.

Chang, T., Lee, C.C., Hung. K., Lee, K.H. (2014) Does military spending really matter for economic growth and China and G7 countries: the roles of dependency and heterogeneity. Defence and Peace Economics, 25(2), 177-191.

Chen, P.F., Lee, C.C., Chiu, Y.B. (2014). The nexus between defense expenditure and economic growth: new global evidence. Economic Modelling, 36, 474-483.

Cuaresma, J.C., Reitschuler, G. (2004) A nonlinear defence-growth nexus? Evidence from the US economy. Defence and Peace Economics, 15(1), 71-82.

Dimitraki O., Ali, F.M. (2015) The long-run causal relationship between military expenditure and economic growth in China: revisited. Defence and Peace Economics, 26(3), 311-326.

Dune, J.P., Smith, R.P., Willenbockel, D. (2005) Models of military expenditure and growth: a critical view. Defence and Peace Economics, 16(6), 449-461.

Dunne, J.P., Nikolaodou, E., Mylonidis, N. (2003) The demand for military spending in the peripheral economics of Europe. Defence and Peace Economics, 14(6), 114. 
Dunne, J.P., Smith, R.P. (2010) Military expenditure and Granger causality: a critical review. Defence and Peace Economics, 21(5-6), 427-441.

Dunne, J.P., Tian, N. (2013) Military expenditure and economic growth: A survey. The Economics of Peace and Security Journal. 8(1), 5-11.

Dunne, J.P., Uye M. (2010) Military spending and development. pp. 293-305 in A. Tan, ed. The global arms trade: a handbook. London: Routledge.

Furuoka, F., Oishi, M., Karim, M.A. (2014) Military expenditure and economic development in China: an empirical inquiry. Defence and Peace Economics, DOI:10.1080/10242694.2014.898383.

Gozhor, G. (2014) Causal relation between economic growth and domestic credit in the economic globalization: evidence from Hatemi-J's test. Journal of International Trade \& Economic Development: An International and Comparative Review. doi:10.1080/09638199.2014.908325

Hatemi-J (2012) Asymmetric causality tests with an application. Empirical Economics, 43(1), 447-456.

Hatemi-J (2011) Asymmetric Panel Causality Tests with an Application to the Impact of Fiscal Policy on Economic Performance in Scandinavia, MPRA Paper 55527, University Library of Munich, Germany.

Hiemstra, C., Jone., J.(1994) Testing for linear and nonlinear Granger causality in the stock price-volume relation. Journal of Finance, 49(5), 1639-1664.

Joerding,W. (1986). Economic growth and defense spending: Granger causality. Journal of Economic Development, 21, 35-40.

Khalid, M.A., Mustapha, A.B. (2014) Long-run relationships and causality tests between military expenditure and economic growth in India. The Economics and Finance Letters, 1(6), 49-58.

Kollias C., Mylonidis, N., Paleologou, S.M. (2007) A panel data analysis of the nexus between defence spending and growth in the European Union. Defence and Peace Economics, 18(1), 75-85.

Kollias, C., Paleologou, S.M. (2013) Guns, highways and economic growth in the United States. Economic Modelling, 30, 449-455.

Lai, C.N., Hung, B.N., Yang, C.Y. (2005) Defense spending and economic growth across the Taiwan Straits: a threshold regression model. Defence and Peace Economics, 16(1), 45-57.

Mocan, H.N., Bali, T.G.(2010) Asymmetric Crime Cycles. Review of Economic and Statistics, 92(4), 899-911.

Nikolaodou, E. (2008) The demand for military expenditure: evidence from the EU15 (1961-2005). Defence and Peace Economics, 19(4), 273-292. 
Pan, C.I., Chang, T., Wolde-Rufael, Y. (2014) Military spending and economic growth in the Middle East countries: bootstrap panel causality test. Defence and Peace Economics. DOI:10.1080/10242694.2014.891356

Pesaran, M.H., Ullah, A., Yamagata, T. (2008) A bias-adjusted LM test of error crosssection independence. Econometrics J. 11, 105-127.

Perlo-Freeman, S., Fleurant, A., Wezeman, P.D. Wezeman, S.T.(2015) Trends in world military expenditure, 2014- SIPRI Fact Sheet. Stockholm International Peace Research Institute. Retrieved 20 May 2015. At http://books.sipri.org/product_info?c_product_id=496

Pradhan, R.P. (2010) Defense spending and economic growth in China, India, Nepal and Pakistan: evidence from cointegrated panel analysis. International Journal of Economics and Finance, 2(4), 65-74.

Safdari, M., Keramati, J., Mahmoodi, M.(2011). The relationship between military expenditure and economic growth in four Asian countries. Chinese Business Review, 10(2), 112-118.

Shahbaz, M., Shabbir, M.S. (2012) Military spending and economic growth in Pakistan: new evidence from rolling window approach. Ekonomska istraživanja, 25(1), 144-159.

Swamy, P.A.V.B. (1970) Efficient inference in a random coefficient regression model. Econometrica 38, 311-323.

Tiwari, A., Tiwari, A.P. (2010) Defense expenditure and economic growth: evidence from India. Focus of Journal of Cambridge Studies, 5(2-3), 117-131.

Tiwari, A.K. (2014) The asymmetric Granger-causality analysis between energy consumption and income in the United States. Renewable and Sustainable Energy Reviews, 36, 362-369.

Tiwari, A.K., Shahbaz, M. (2013) Does defence spending stimulate economic growth in India? A revisit. Defence and Peace Economics, 24(4), 371-395.

Toda, H.Y., Yamamoto, T.(1995) Statistical inferences in vector autogressions with possible integrated process. Journal of Econometrics, 66, 225-250.

Topcu, M., Aras I. and Erdoğan E. (2013). A New Look at Military ExpendituresGrowth Nexus in the EU: Old Members vs. New Members. International Journal of Economic Sciences, 2(3), 143-151.

Topcu, M., Aras, I. (2013) Economic impacts of military expenditures: a comparative analysis of superpowers of the world. Actual Problems of Economics, 145(4), 495-506.

Topcu, M., Aras, I. (2015) Defense spending and economic growth: extended empirical analysis for the European Union. Defence and Peace Economics, 26(2), 233-246. 
Yang, A.J.F., Trumbull, W.N., Yang, C.W., Hung, B.N. (2011) On the relationship between military expenditure, threat, and economic growth: a nonlinear approach. Defence and Peace Economics, 22(4), 449-457.

Yilgör, M., Karagöl E.T., and Saygili, C.A. (2014) Panel Causality analysis between defence expenditure and economic growth in developed countries. Defence and Peace Economics, 25(2), 193-203.

Zhong, M., Chang, T., Tang, D.P., Wolde-Rufael, Y. (2014) The causal nexus between military spending and unemployment in the G7: a bootstrap panel causality test. Defence and Peace Economics. DOI:10.1080/10242694. 2014.994835 . 
Table 1. Descriptive Statistics $\dagger$

\begin{tabular}{cccccc}
\hline Variables & Countries & Mean & Std. Dev. & Min & Max \\
\hline \multirow{6}{*}{ GDP } & China & 2302.219 & 1521.03 & 657.4866 & 5567.404 \\
& France & 36537.04 & 3297.11 & 30846.04 & 40837.43 \\
& Japan & 40246.37 & 2750.54 & 33360.39 & 44256.53 \\
& Russia & 16642.22 & 2831.46 & 13937.46 & 23318.26 \\
& Saudi Arabia & 8479.698 & 2078.48 & 5487.51 & 11692.71 \\
& United States & 43486.55 & 5382.99 & 35083.88 & 50249.23 \\
\hline \multirow{5}{*}{ Military } & China & 63316.35 & 49414.99 & 18336.00 & 171381.00 \\
& France & 65612.23 & 3093.00 & 61576.00 & 70986.00 \\
& Japan & 57062.88 & 4750.38 & 45697.00 & 61460.00 \\
& Russia & 86899.46 & 96977.38 & 20800.00 & 371073.00 \\
& Saudi Arabia & 16642.22 & 2831.46 & 13937.46 & 23318.26 \\
& United States & 522115 & 112119.90 & 378533.00 & 720386.00 \\
\hline
\end{tabular}

$\dagger$ The whole sample period covers 1988 to 2013, resulting in a total of 26 annual observations in level.

Table 2. Cross-sectional Dependence and Slope Homogeneity Tests ${ }^{\dagger}$

\begin{tabular}{lrlll}
\hline \multicolumn{2}{c}{ Cross-sectional Dependence Test } & & \multicolumn{2}{c}{ Slope Homogeneity Test } \\
\cline { 1 - 2 } \cline { 5 - 6 }$C D_{B P}(\mathrm{LM})$ & $164.525^{* * *}$ & & $\tilde{\Delta}$ & $15.479^{* * *}$ \\
$C D_{L M}$ & $26.204^{* * *}$ & & $\tilde{\Delta}_{a d j}$ & $16.418^{* * * *}$ \\
$C D$ & $5.402 * * *$ & & Swamy Stat & $25.456^{* * * *}$ \\
$L M_{a d j}$ & $26.084^{* * *}$ & & & \\
\hline
\end{tabular}

${ }^{\dagger}$ All variables are transformed into the natural log form in order to perform the cross-sectional dependence and slope homogeneity tests. "****" represents $1 \%$ significance level.

Table 3. IPS Unit Root Test Results

\begin{tabular}{|l|l|l|l|l|}
\hline & \multicolumn{2}{|c|}{ Level } & \multicolumn{2}{c|}{ First-Difference } \\
\hline Variable & Constant & Constant+Trend & Constant & Constant+Trend \\
\hline GDP & & & - & \\
\hline & 1.789 & 0.425 & $5.604 * * *$ & $-4.459 * * *$ \\
\hline Military Expenditures & -0.514 & 0.031 & - & \\
\hline
\end{tabular}

Note:*** indicates the rejection of the null hypothesis of unit root at $1 \%$ level of significance. 
Table 4. Symmetric and Asymmetric Panel Granger Causality Test Results

\begin{tabular}{|c|c|c|c|c|c|c|}
\hline COUNTERY & $\begin{array}{c}\text { NULL } \\
\text { HYOTHESIS }\end{array}$ & $\begin{array}{c}\text { P-Value } \\
\text { of } \\
\text { Causality } \\
\text { Test }\end{array}$ & $\begin{array}{c}\text { Significant } \\
\text { Causal } \\
\text { Parameter } \\
\text { Value }\end{array}$ & $\begin{array}{c}\text { NULL } \\
\text { HYOTHESIS }\end{array}$ & $\begin{array}{c}\text { P-Value } \\
\text { of } \\
\text { Causality } \\
\text { Test }\end{array}$ & $\begin{array}{c}\text { Significant } \\
\text { Causal } \\
\text { Parameter } \\
\text { Value }\end{array}$ \\
\hline \multirow[t]{3}{*}{ China } & $D \nRightarrow Y$ & 0.0063 & 0.197030 & $Y \nRightarrow D$ & 0.2552 & \\
\hline & $D^{-} \neq>Y^{-}$ & NA & & $Y^{-} \neq D^{-}$ & NA & \\
\hline & $D^{+} \neq>Y^{+}$ & 0.0004 & 0.249709 & $Y^{+} \nRightarrow D^{+}$ & 0.3543 & \\
\hline \multirow[t]{3}{*}{ France } & $D \nRightarrow Y$ & 0.2001 & & $Y \nRightarrow D$ & 0.1717 & \\
\hline & $D^{-} \nRightarrow>Y^{-}$ & 0.1123 & & $Y^{-} \neq D^{-}$ & 0.0041 & 0.927676 \\
\hline & $D^{+} \neq>Y^{+}$ & 0.1888 & & $Y^{+} \nRightarrow D^{+}$ & 0.0002 & -0.941577 \\
\hline \multirow[t]{3}{*}{ Japan } & $D \nRightarrow Y$ & 0.1940 & & $Y \neq>D$ & 0.3448 & \\
\hline & $D^{-} \neq>Y^{-}$ & 0.0000 & 1.800843 & $Y^{-} \nRightarrow D^{-}$ & 0.7354 & \\
\hline & $D^{+} \neq>Y^{+}$ & 0.9255 & & $Y^{+} \neq>D^{+}$ & 0.3801 & \\
\hline \multirow[t]{3}{*}{ Russia } & $D \nRightarrow Y$ & 0.0468 & -0.078996 & $Y \neq D$ & 0.0335 & 1.401690 \\
\hline & $D^{-} \nRightarrow>Y^{-}$ & 0.7073 & & $Y^{-} \nRightarrow D^{-}$ & 0.4648 & \\
\hline & $D^{+} \neq>Y^{+}$ & 0.2918 & & $Y^{+} \neq D^{+}$ & 0.0041 & 1.947112 \\
\hline \multirow[t]{3}{*}{ Saudi Arabia } & $D \nRightarrow>$ & 0.8965 & & $Y \neq>D$ & 0.0523 & 1.372407 \\
\hline & $D^{-} \nRightarrow>Y^{-}$ & 0.5724 & & $Y^{-} \nRightarrow>D^{-}$ & 0.0000 & 4.730338 \\
\hline & $D^{+} \neq>Y^{+}$ & 0.2573 & & $Y^{+} \neq>D^{+}$ & 0.0177 & 2.979637 \\
\hline \multirow[t]{3}{*}{ US } & $D \nRightarrow>Y$ & 0.5899 & & $Y \neq D$ & 0.0019 & -1.445270 \\
\hline & $D^{-} \nRightarrow>Y^{-}$ & 0.7576 & & $Y^{-} \nRightarrow D^{-}$ & 0.1659 & \\
\hline & $D^{+} \neq>Y^{+}$ & 0.9313 & & $Y^{+} \nRightarrow D^{+}$ & 0.0002 & -1.025666 \\
\hline
\end{tabular}

1. The denotation $\mathrm{D} \neq>\mathrm{Y}$ implies that defense does not Granger cause GDP in the underlying panel model.

2. The denotation $Y \nRightarrow>D$ implies that GDP does not Granger cause defense in the panel.

3. The vector $\left(D^{+}{ }_{s} Y^{+}\right)$represents the positive cumulative sums and the vector $\left(D^{-}{ }_{s}^{-} Y^{-}\right)$denotes the negative cumulative sums of the underlying variables.

4. The optimal lag order in the panel model is chosen to be one since this lag order minimizes the information criterion defined in equation (2). An additional unrestricted lag was included in the model in order to account for the unit root as suggested by Toda and Yamamoto (1995).

5. In the case of China there were not negative changes in the defense expenditure during the period of study. Therefore, the causality tests with regard to negative cumulative chocks could not be implemented for China. 


\section{APPENDIX}

Figure A1: Plot of Per Capita Real GDP

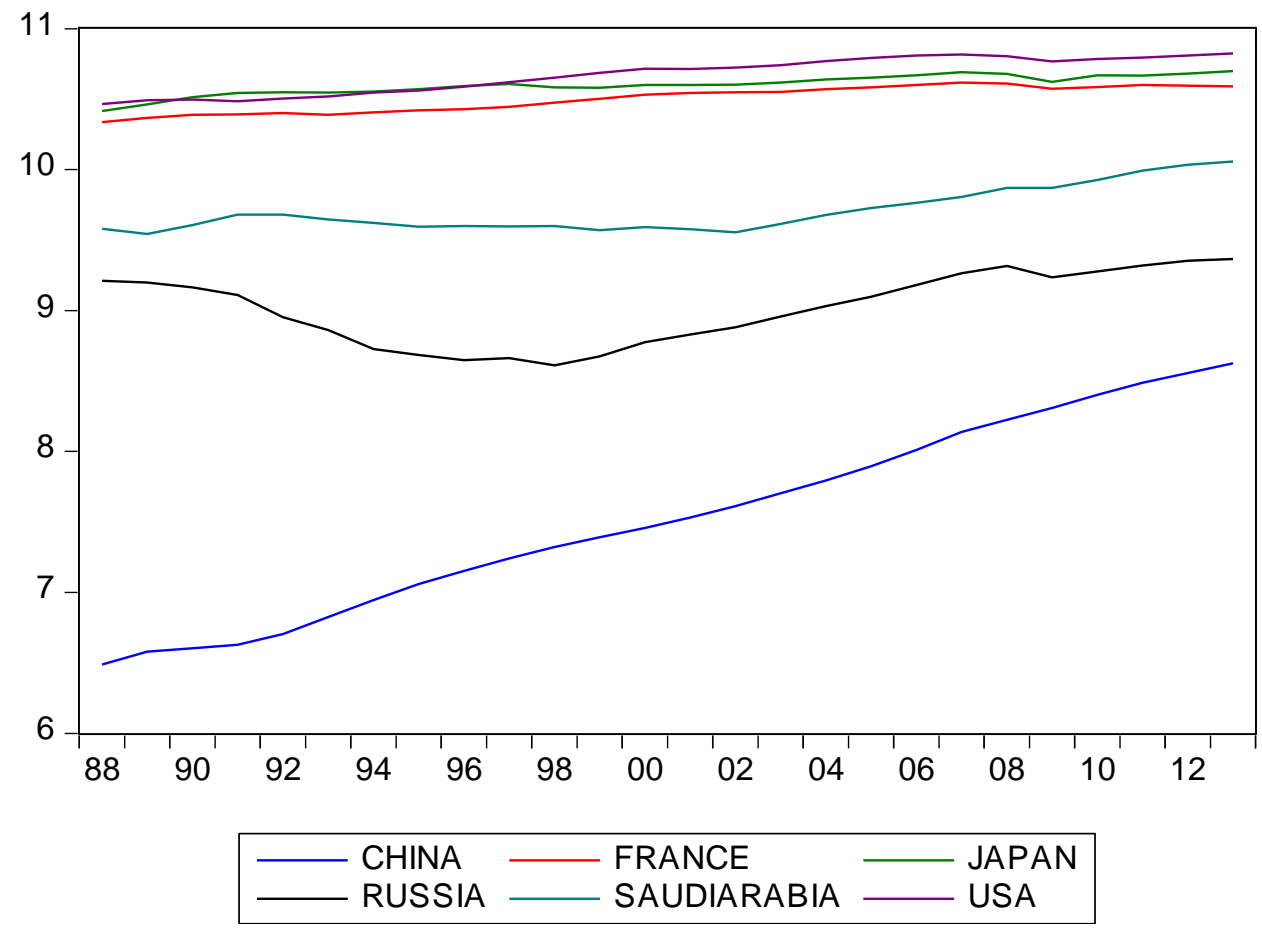

Figure A2: Plot of Per Capita Real Military Expenditures

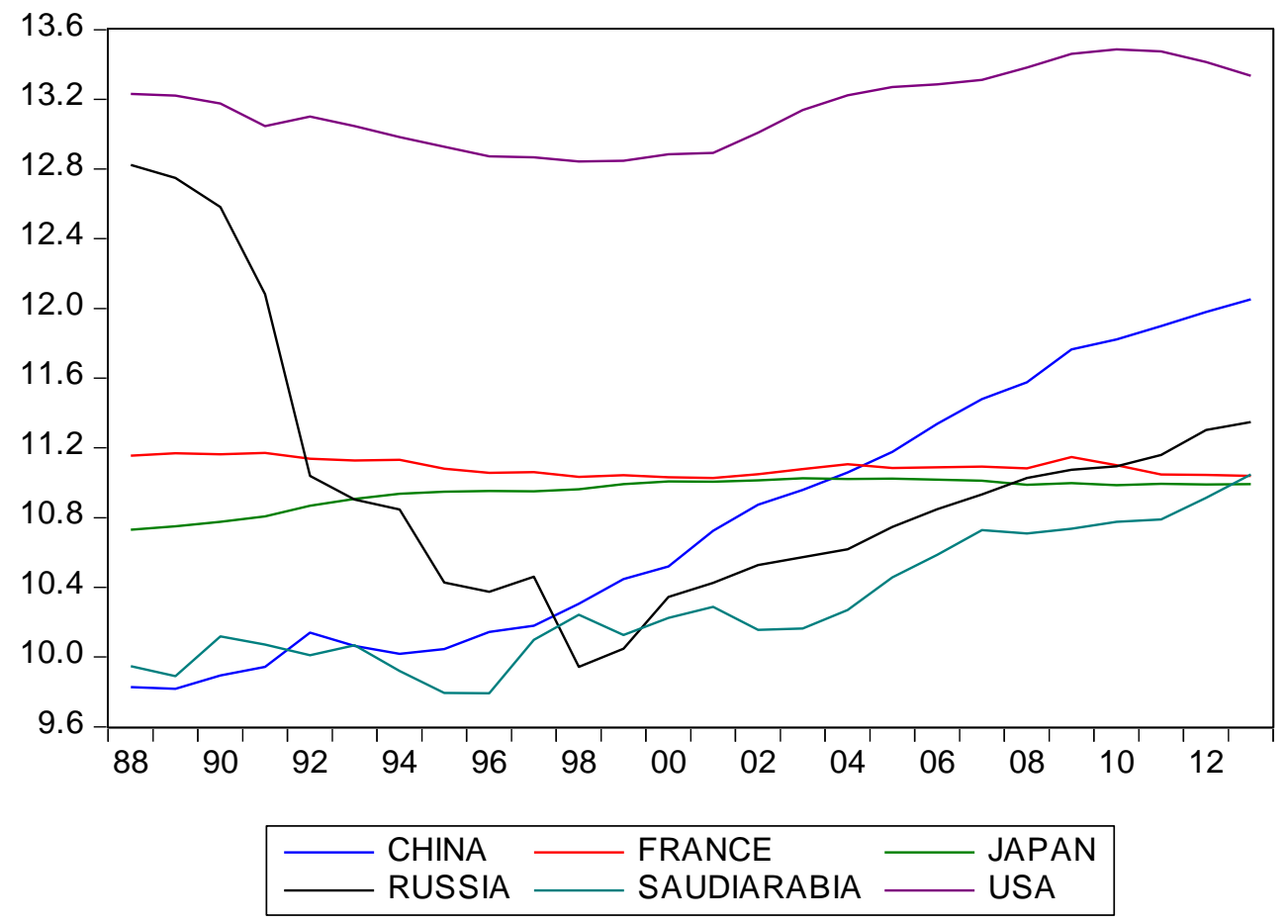

